\title{
Estimation of serum Adenosine Deaminase (ADA) level in sickle cell disease (SCD) and its association with reticulocyte count in a rural population of Chhattisgarh state
}

\author{
Mahendra Gandhe ${ }^{1}$, Harshal Kawanpure ${ }^{2, *}$, A. P. Dongre ${ }^{3}$, Swapnali Gandhe ${ }^{4}$ \\ ${ }^{1,2}$ Associate Professor, ${ }^{1}$ Dept. of Biochemistry, ${ }^{2}$ Dept. of Biochemistry, ${ }^{3}$ Professor \& HOD, Dept. of Forensic \\ Medicine, ${ }^{4}$ Junior Resident, Dept. of Dentistry, Chandulal Chandrakar Memorial Medical College, Durg, \\ Chattisgarh, India
}

*Corresponding Author:

Email: hkawanpure@gmail.com

\begin{abstract}
Prevalence of Sicklecell disease (SCD) is ranging from 1 to $40 \%$ and more in state like Chhattisgarh because of more share of Tribal population by this state in India. Genetic mutation at a sixth position of the $\beta$-globin chain (replacement of glutamic acid by valine) is the biochemical basis of this abnormality. Tissue specific increase of adenosine deaminase is related with lysis of RBC membrane in sickle cell disease. To know the pathology and biochemical basis of increase in serum adenosine deaminase in SCD is ardent. Prospective case-control study is conducted by taking thirty SCD cases [from Durg District of Chhattisgarh State] attending General Medicine OPD in our Medical College. Thirty age and sex matched healthy volunteers were selected as controls from same population. ADA estimation done by enzymatic-kinetic method. Complete hemogram done by Beckman Coulter and retiuculocyte count done by direct microscopic examination. Adenosine deaminase level in SCD was higher as compare to control group and difference is statistically highly significant i.e. p value $0.00(<0.01)$. Comparing to controls, Reticulocyte count was significantly less in SCD i.e. p value $0.049(<0.05)$. SCD cases were having significantly increased ADA level as compared to healthy volunteers. ADA was not any having correlation with reticulocyte count. Estimation of Adenosine Deaminase level can be helpful for knowing pathophysiology of complications occurring in sickle cell disease patients.
\end{abstract}

Keywords: Adenosinedeaminase, Reticulocyte count.

Received: $13^{\text {th }}$ October, 2017

\section{Introduction}

Prevalence of Sickle cell disease (SCD) is ranging from 1 to $40 \%$ and more in state like Chhattisgarh because of more share of Tribal population by this state in India. ${ }^{1,2}$ Genetic mutation at a sixth position of the $\beta$-globin chain (replacement of glutamic acid by valine) is the biochemical basis of this abnormality., According to census of 2011, tribal population is around $8.6 \%$ of total population of India (67.8 million people) which is majorly present in the states of Madhya Pradesh, Maharashtra, Odisha, Gujarat, Rajasthan, Jharkhand, Chhattisgarh, Andhra Pradesh, West Bengal and Karnataka. ${ }^{5}$

Being housekeeping gene; genetic expression of the Adenosine deaminase (ADA) gene present in almost all the tissues. ${ }^{6}$ Highest genetic expression of this gene is in special white blood cells called as lymphocytes. This specialized cell protects our body from different infections. Normally, RBCs (Red blood cells) have less expression of ADA gene. ADA is important for irreversible deamination of deoxyadenosine (harmful product from DNA breakage) to harmless product deoxyinosine.
Accepted: $13^{\text {th }}$ November, 2017

Overproduction of ADA in RBCs causes its lysis and affects its longevity.

Polymerization of deoxyHbS with formation of long fibers within the RBCs causing a sickle shape which eventually leads to increased RBCs lyses and vaso-occlusion by sickle red cells. ${ }^{7,8}$ However, there are different clinical presentations of SCD patients and there are several factors that may trigger vaso-occlusive crises in these patients. ${ }^{9}$

There are different biomarkers of SCD and its increased or decreased levels have been associated with different pathological conditions associated with it. ${ }^{10}$ Very few biomarkers gives prognostic information related to the management of the SCD. Currently, hemoglobin percentage measurement, fetal hemoglobin levels, reticulocyte counts and WBC counts are the primary prognostic tools for the management of pathological condition in SCD. ${ }^{11}$

Extensive clinical trials are needed to identify unambiguous independent biomarkers for identifying the severity of SCD and susceptibility to RBC membrane damage and its breakage and formation sickled RBCs. 
Changes in the level of Adenosine deaminase can be associated with the susceptibility to RBC membrane damage and its breakage and formation sickled RBCsand can be act as biomarker for affected immunity in the SCD cases. $^{12}$

In this study, we tried to find out the level serum ADA in SCD. We tried to find out the association of the ADA enzyme level with the reticulocyte count as marker of severity of RBCs membrane damage and its lyses occurring in sickle cell disease cases. Adenosine deaminase level can be act as a biomarker for RBCs lyses in the SCD cases.

\section{Aim and objectives}

1. To investigate the serum adenosine deaminase (ADA) status in SCD cases and its comparison with healthy controls of rural population of Durg district of Chhattisgarh State.

2. To associate Serum ADA level with reticulocyte count as a marker of RBC membrane lysis in SCD cases.

\section{Material and Methods}

Study population: This was a prospective case control study conducted at CCM Medical College, Durg.

Inclusion criteria: Thirty SCD cases aging 18 to 30 years age group attending General Medicine OPD in our medical college from rural area of Durg District of Chhattisgarh State were selected as study participants. Thirty healthy age and sex matched volunteers from same population were selected as control for this study.

Exclusion criteria: Participants who were suffering from any diseases which can affect ADA levels such as fresh or old cases of pulmonary or extra-pulmonary tuberculosis or any chronic diseases such as liver diseases or Type 1 or Type 2 Diabetes mellitus or cancer or severe combined immunodeficiency (Adenosine deaminase deficiency), cirrhosis of liver, pregnant or lactating women, leprosy, HIV, chronic malnutrition or participants taking adenosine medications were excluded from the study. Those who are not giving valid written consent were also removed from this study.

Permission to conduct above study was obtained from the Institutional Human Ethics Committee (IHEC). Informed consent in written form was obtained after explaining this study to cases and controls. From the recruited participants, proper medical history was obtained. Then the following physiological and anthropometric parameters were measured in study participants.

Physiological Parameters: Both groups were assessed for anthropometric parameters namely weight (in $\mathrm{kg}$ ), waist (in cm.), Height (in meters), Body mass index and Blood pressure.

General obesity: Accurate height was measured in an erect and standing position of participants with bare foot, against a vertical scale. The body weight of the study participants (minimally clothes and bare foot) were measured using electronic weighing scale and it was recorded accurately. Body mass index (BMI) was calculated using the following formula $\mathrm{BMI}=$ Weight (in $\mathrm{kg}$ )/ Height (in $\mathrm{m}^{2}$ ).

Central obesity: Waist circumference (in $\mathrm{cm}$ ) was measured by using measuring tape at the level of umbilicus. Two measurements of waist circumference [one after inspiration and other following expiration] taken in standing position. Average of this two measurements taken for final calculation of waist circumference.

Biochemical parameters: Then three $\mathrm{ml}$ blood were collected from the subject for following biochemical estimation in one plain bulb for Serum ADA level and in one EDTA bulb for reticulocyte count, $\mathrm{Hb} \%$ and TLC,DLC.

\section{Biochemical analysis of cardio-metabolic risk factors}

Three $\mathrm{ml}$ of venous blood sample was collected under all aseptic precautions from all study participants. Serum in plain bulb was separated immediately by centrifugation (2500 rpm for 10 minutes). Biochemical and hematological parameters were analysed as follows: Serum ADA level, reticulocyte count, $\mathrm{Hb} \%$ and TLC, DLC.

All the above mentioned biochemical parameters estimated using IFCC approved procedures. The external quality control was evaluated based on QC samples provided by $\mathrm{M} / \mathrm{s}$ Biorad USA. The external quality assessment (EQAS) was based on the QC samples provided by Clinical Biochemistry Lab, CMC Vellore.

\section{Estimation of Adenosine deaminase}

Estimation of serum ADA level was done by Guisti and Galanti method of enzymatic-kinetic method using ADA kit supplied by Tulip Diagnostics. (P) Ltd. Reticulocyte Count was done by direct microscopy. ADA causes hydrolytic cleavage of adenosine to ammonia and inosine. Intensity of blue indophenols complex formed [when ammonia reacts with a phenol and hypochlorite and sodium nitroprussidein an alkaline medium] is directly 
proportional to the amount of ADA present in the sample. ${ }^{13}$

\section{Statistical analysis}

The statistically mean difference in SCD cases and healthy volunteers were calculated using the independent student's t test. SPSS 23.0 version was used for all statistical analysis. Correlation analysis between adenosine deaminase level with reticulocyte count were assessed by two-tailed Pearson's correlation. A significant level of $95 \%$ was chosen for all tests. The level of significance was taken as $(\mathrm{P}<0.05)$.

\section{Result}

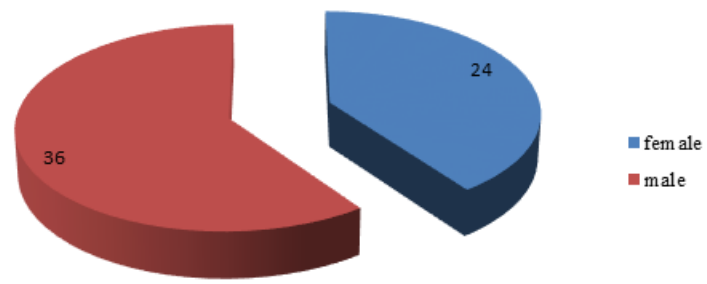

Fig 1: Pie diagram showing sex distribution of study participants

Table 1: Comparison of different parameters in sickle cell disease cases with controls

\begin{tabular}{|c|c|c|c|c|c|c|}
\hline Parameters & ID & Number & Mean & $\begin{array}{c}\text { Std. } \\
\text { Deviation }\end{array}$ & p value & $95 \% \mathrm{CI}$ \\
\hline \multirow{2}{*}{$\begin{array}{l}\text { Adenosine } \\
\text { Deaminase }\end{array}$} & Case & 30 & 41.20 & 9.70 & \multirow[b]{2}{*}{$0 * *$} & \multirow[b]{2}{*}{$(17.20,25.93)$} \\
\hline & Control & 30 & 19.63 & 6.98 & & \\
\hline \multirow{2}{*}{$\begin{array}{l}\text { Reticulocyte } \\
\text { count }\end{array}$} & Case & 30 & 0.51 & 0.27 & \multirow[b]{2}{*}{$0.049 *$} & \multirow{2}{*}{$(-0.31-0.00)$} \\
\hline & Control & 30 & 0.67 & 0.33 & & \\
\hline \multirow[b]{2}{*}{ Hemoglobin $\%$} & Case & 30 & 11.99 & 2.22 & \multirow[b]{2}{*}{$0.002 * *$} & \multirow{2}{*}{$(-2.96,-0.68)$} \\
\hline & Control & 30 & 13.81 & 2.21 & & \\
\hline \multirow[b]{2}{*}{ TLC } & Case & 30 & 7253.33 & 1469.16 & \multirow[b]{2}{*}{0.416} & \multirow[t]{2}{*}{$(-1376.98,576.99)$} \\
\hline & Control & 30 & 7653.33 & 2233.40 & & \\
\hline \multirow[b]{2}{*}{ Granulocytes } & Case & 30 & 52.70 & 6.62 & \multirow[b]{2}{*}{0.068} & \multirow{2}{*}{$(-8.09,0.29)$} \\
\hline & Control & 30 & 56.60 & 9.37 & & \\
\hline \multirow[b]{2}{*}{ Lymphocytes } & Case & 30 & 41.03 & 6.72 & \multirow[b]{2}{*}{0.119} & \multirow{2}{*}{$(-0.87,7.46)$} \\
\hline & Control & 30 & 37.74 & 8.93 & & \\
\hline \multirow[b]{2}{*}{ Monocytes } & Case & 30 & 6.27 & 0.58 & \multirow[b]{2}{*}{$0.002 * *$} & \multirow{2}{*}{$(0.31,1.35)$} \\
\hline & Control & 30 & 5.43 & 1.28 & & \\
\hline \multirow{2}{*}{$\begin{array}{l}\text { Waist } \\
\text { circumference }\end{array}$} & Case & 30 & 80.90 & 3.09 & \multirow[b]{2}{*}{$0.008 * *$} & \multirow{2}{*}{$(-6.10,-0.97)$} \\
\hline & Control & 30 & 84.43 & 6.31 & & \\
\hline \multirow{2}{*}{$\begin{array}{l}\text { Body } \\
\text { index }\end{array}$} & Case & 30 & 18.96 & 2.81 & \multirow[b]{2}{*}{$0.001 * *$} & \multirow{2}{*}{$(-3.77,-0.94)$} \\
\hline & Control & 30 & 21.32 & 2.67 & & \\
\hline \multirow[b]{2}{*}{ Height } & Case & 30 & 1.62 & 0.06 & \multirow[b]{2}{*}{0.323} & \multirow{2}{*}{$(-0.05,0.02)$} \\
\hline & Control & 30 & 1.64 & 0.07 & & \\
\hline \multirow[b]{2}{*}{ Weight } & Case & 30 & 49.50 & 6.14 & \multirow[b]{2}{*}{$0 * *$} & \multirow{2}{*}{$(-11.78,-3.68)$} \\
\hline & Control & 30 & 57.23 & 9.23 & & \\
\hline
\end{tabular}

$*_{\text {- }}$ significant $*_{*} *_{\text {- Highly significant }}$

Total participants in our study were 36 male and 24 female (Fig. 1). Mean age of cases were $(25+3.9)[$ [Mean + Std. deviation] and mean age of controls were $(24+4.1)$. Mean serum ADA level in sickle cell disease was higher as compare to control group and difference is statistically highly significant i.e. p value $0.00(<0.01)$. Reticulocyte count was significantly less in cases as compared to controls i.e. $\mathrm{p}$ value 0.049 (<0.05). Mean $\mathrm{Hb} \%$ was significantly less in cases $(11.99 \pm 2.22)$ as compared to controls $(13.81 \pm 2.21)$ i.e. p value $0.002(<0.01)$. Monocytic count $(6.27 \pm 0.58)$ was significantly 
higher in cases as compared to controls $(5.43 \pm 1.28)$ i.e. p value $0.002(<0.01)$. Waist circumference $(80.90 \pm 3.09)$ was lower in cases as compared to controls $(84.43 \pm 6.31)$ and difference was statistically significant i.e. p value $0.008(<0.01)$. Body mass index $(18.96 \pm 2.81)$ was significantly lower in cases as compared to controls $(21.32 \pm 2.67)$ i.e. $p$ value $0.001(<0.01)$. Body weight $(49.50 \pm 6.14)$ was significantly lower in cases as compared to controls $(57.23 \pm 9.23)$ i.e. p value $0.0(<0.01)$ [as shown in Table 1]. No significant difference found in mean levels of total leucocytes count $((7253.33 \pm 1469.16)$ versus controls $(7653.33 \pm 2233.40)$, granulocytes $(52.70 \pm 6.62)$ versus controls $(56.60 \pm 9.37)$, lymphocytes $(41.03 \pm 6.72)$ versus controls $(37.74 \pm 8.93)$, and height $(1.62 \pm 0.06)$ versus controls (1.64 \pm 0.07$)$.

Table 2: Correlation of Adensinedeaminase with different parameters in study participants

\begin{tabular}{|l|c|c|}
\hline \multicolumn{1}{|c|}{ Correlation parameters } & $\begin{array}{c}\text { Pearson } \\
\text { Correlation }\end{array}$ & p Value \\
\hline Adensinedeaminase with Lymphocyte & $0.280^{*}$ & 0.035 \\
\hline Adensinedeaminase with reticulocyte count & $-0.331^{* *}$ & 0.01 \\
\hline Adensinedeaminase with hemoglobinpercentage & -0.17 & 0.194 \\
\hline Adensinedeaminase with body mass index & $-0.267^{*}$ & 0.039 \\
\hline Adenosine deaminase with Granulocyte & $-0.321^{*}$ & 0.012 \\
\hline
\end{tabular}

* Correlation is significant at the 0.05 level (2-tailed).

Correlation analyses were done between adenosine deaminase with $\mathrm{Hb} \%$, reticulocyte count, lymphocytes, granulcoytes and physiological parameter (Body mass index). (Table 2). There were no significant correlation between adenosine deaminase and lymphocyte count $(\mathrm{r}=0.280$ and $\mathrm{p}$ value $<0.05)$. There were no significant correlation between adenosine deaminase and reticulocyte count $(r=-0.331$ and $\mathrm{p}$ value<0.01). There were no significant correlation between adenosine deaminase and body mass index $(r=-0.267$ and $p$ value $<0.05)$. There were no significant correlation between adenosine deaminase and granulocytes $(\mathrm{r}=-0.321$ and $\mathrm{p}$ value $<0.05$ ). These data confirms significantly increase in the level of serum ADA in SCD cases.

\section{Discussion}

Being housekeeping gene; genetic expression of the Adenosine deaminase (ADA) gene present in almost all the tissues. Highest genetic expression of this gene is in special white blood cells called as lymphocytes. This specialized cell protects our body from different infections. Normally, RBCs (Red blood cells) have less expression of ADA gene. ADA is important for irreversible deamination of deoxyadenosine (harmful product from DNA breakage) to harmless product deoxyinosine. Overproduction of ADA in RBCs causes its lyses and affects its longevity. In our study, mean serum ADA level (41.20 \pm 9.70$)$ in SCD cases was higher as compared to control group $(19.63 \pm 6.98)$ and difference is statistically highly significant i.e. $p$ value $0.00(<0.01)$.
Damaged RBC membrane releases Adenosine deaminase into plasma and it helps in the irreversible deamination of adenosine to inosine and decreases extracellular adenosine level. ADA and its substrate adenosine plays an important role RBC membrane lyses occurring in sickle cell disease. However, etio-pathology of increased adenosine level is not clear and assumed due to increased ATP release from cellular damage. Adenosine helps in many biological reactions such as reduction of hemolysis-induced vasculopathy by acting on adenosine A (2A) receptors. ${ }^{13}$

One of the previous study shown that, adenosine treatment in SCD helps to increase blood flow with pain alleviation and decreases severity of vaso-occlusive crisis and cellular damage. ${ }^{14}$ Production of the adenosine is increased in hypoxic conditions and its elevationis beneficial to counter acts hypoxic damage at tissue and blood vessel level. Vascular damage protective effects of Adenosine is decreased [because of its metabolism by adenosine deaminase enzyme released by injured RBCs under hypoxic conditions].

Reticulocyte count $(0.51 \pm 0.27)$ [mean \pm Standard deviation] was significantly less in cases as compared to controls $(0.67 \pm 0.33)$ i.e. $\mathrm{p}$ value $0.049(<0.05)$. Correlation analyses were performed between ADA with $\mathrm{Hb} \%$ and reticulocyte count. In this study, no significant correlation between ADA and reticulocyte count was found. In one of the previous studies, done on children with hemolytic anemia shown significant positive association between Adenosine deaminase and reticulocyte count $(\mathrm{r}=0.548$ and $\mathrm{P}<0.0001)$ and significant negative association with Hemoglobin percentage ( $\mathrm{r}=-$ 
0.747 and $\mathrm{p}<0.0001) .{ }^{15}$ In contrast to this, in our study, we were not having any significant correlation of adenosine deaminase with retciculocyte count and Hemoglobin percentage. One of the previous studies, it was done in the urban area of Mysore Karnataka State where prevalence of malnutrition is less as compared to Chhattisgarh State. ${ }^{15}$ Our study participants were from tribal area and rural population, where malnutrition or under-nutrition or fewer intakes of micronutrients are quite common. Our case group was having significantly lower body mass index, waist circumference and weight as compared to the control group. This is also one of the reasons of low reticulocyte count in study cases group. Nutritional status is indicated by body mass index, and our study shown consistent and same findings of significant lower body mass index in rural SCD cases $(18.96 \pm 2.81)$ from Durg District compared to the control i.e. $(21.32 \pm 2.67)$ and $p$ value $0.001(<0.01)$. Our study reflected low body weight in our study group as compared to the control and the difference was statistically significant. Our study is showing similar findings consistent with one of the previous studies. ${ }^{16}$ Mean hemoglobin percentage $(11.99 \pm 2.22)$ was significantly lower in cases as compared to controls $(13.81 \pm 2.21)$ i.e. $\mathrm{p}$ value $0.002(<0.01)$. One of the previous studies, done on children of aged 3 years shown that severe baseline anaemia is associated with complications such as leg ulcer, microalbuminuria and echographic pulmonary hypertension in African SCD cases ${ }^{17}$ One of the previous studies, done on anthropometric and hematological parameters of SCD women shown low hemoglobin percentage $((8.85 \pm 1.92)$ and low mean BMI [ $22.6 \mathrm{~kg} / \mathrm{m}^{2}$ ] as compared to the controls. ${ }^{18}$ In of the previous studies, done on pediatric age group, there was no association between BMI and vaso-occlusive crisis. ${ }^{19}$ Comparison of blood and anthropometric parameters such as $\mathrm{Hb} \%$, weight, height and BMI between rural and urban 8 to15 years aged children population residing in Wardha district of Central India studied in one of the previous research on SCD cases. ${ }^{20}$ This study shown that homozygous sickle cell disease children from rural area were significantly underweight and low BMI [18.5] as compared to urban children. ${ }^{20}$ Our study findings are consistent with this study, showing low BMI in our rural population of SCD cases as compared to the control from same rural population. One of the previous studies shown delayed physical growth and sexual maturity in SCD cases due to under-nutrition leads to low body mass index. ${ }^{21}$
In our study groups, mean waist circumference $(80.90 \pm 3.09)$ was significantly lower in cases as compared to controls $(84.43+6.31)$ i.e. $\mathrm{p}$ value $0.008(<0.01)$. Mean body weight $(49.50 \pm 6.14)$ was significantly lower in cases as compared to controls $(57.23 \pm 9.23)$ i.e. $\mathrm{p}$ value $0.0(<0.01)$ [as shown in Table 1]. Findings of less body weight in SCD cases is consistent with one of the previous studies. $^{22}$ Mean monocytic count $(6.27 \pm 0.58)$ was significantly higher in cases as compared to controls $(5.43 \pm 1.28)$ i.e. $\mathrm{p}$ value $0.002(<0.01)$. There were no significant difference found in mean levels of total leucocytes count $((7253.33 \pm 1469.16) \quad$ versus controls (7653.33 \pm 2233.40$)$, granulocytes $(52.70 \pm 6.62)$

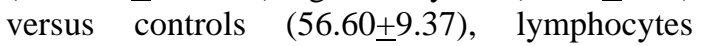
$(41.03 \pm 6.72)$ versus controls $(37.74 \pm 8.93)$, and height $(1.62 \pm 0.06)$ versus controls $(1.64 \pm 0.07)$.

Correlation analyses were done between adenosine deaminase with $\mathrm{Hb} \%$, reticulocyte count, lymphocytes, granulcoytes and physiological parameter (Body mass index). (Table 2) There were no significant correlation between adenosine deaminase and lymphocyte count $(r=0.280$ and $p$ value $<0.05)$. There were no significant correlation between adenosine deaminase and reticulocyte count $(\mathrm{r}=-0.331$ and $\mathrm{p}$ value $<0.01$ ). There were no significant correlation between adenosine deaminase and body mass index $(r=-0.267$ and $p$ value $<0.05)$. There were no significant correlation between adenosine deaminase and granulocytes $(r=-0.321$ and $\mathrm{p}$ value $<0.05)$. These data confirms marked elevation of serum ADA level in SCD cases.

There were no significant correlation between adenosine deaminase and lymphocyte count $(r=0.280$ and $p$ value $<0.05)$. But there was significantly increased lymphocytes in cases $(41.03 \pm 6.72)$ versus controls $(37.74 \pm 8.93)$. $\mathrm{T}$ lymphocytes are having ten times higher level of Adenosine deaminase as compared to erythrocytes. Activation of cell mediated immunity and increased $\mathrm{T}$ lymphocytes may be contributing to increased ADA level. ADA activity is more in lymphcoytes and helps in differentiation of lymphocytes. ${ }^{23}$

This was the first pilot study done in our area on SCD patients from rural area of Durg population of Chhattisgarh state. However, we are planning for large scale study by taking more number of SCD cases for knowing pathophysiology behind increase in ADA level in SCD patients. Though, SCD can be diagnosed by solubility test, serum electrophoresis, HPLC, estimation of Adenosine Deaminase level can be helpful for knowing pathophysiology of complications occurring in sickle cell disease patients. 


\section{References}

1. Chang JC, Kan YW. Antenatal diagnosis of sickle cell anaemia by direct analysis of the sickle mutation.Lancet. 1981;2:1127-9.

2. Kamble M, Chaturvedi P. Epidemiology of sickle cell disease in a rural hospital of central India. Indian Pediatrics. 2000;37:391-6.

3. Deshmukh P, Garg BS, Garg N, Prajapati NC, Bharambe MS. Prevalence of sickle cell disorders in rural Wardha. Indian J Community Med. 2006;31:26-7.

4. Serjeant GR. The case for dedicated sickle cell centres. Indian J Hum Genet. 2006;12:148-51.

5. Patra PK, Chauhan VS, Khodiar PK, Dalla AR, Serjeant GR. Screening for the sickle cell gene in Chhattisgarh state, India: an approach to a major public health problem. J Community Genet. 2011;2:147-51.

6. Eltzschig HK, Thompson LF, Karhausen J, Cotta RJ, Ibla JC, Robson SC, Colgan SP. Endogenous adenosine produced during hypoxia attenuates neutrophil accumulation: coordination by extracellular nucleotide metabolism. Blood. 2004;104:3986-92.

7. Akinsheye I, Klings ES. Sickle cell anemia and vascular dysfunction: the nitric oxide connection. J. Cell. Physiol.2010;224:620-5.

8. Herrick JB. Peculiar elongated and sickle-shaped red blood corpuscles in a case of severe anemia. Arch. Intern. Med. 1910;6:517-21.

9. Pauling L, Itano HA, et al. Sickle cell anemia a molecular disease. Science. 1949;110:543-8.

10. Nolan VG, Wyszynski DF, Farrer LA, Steinberg MH. Hemolysis-associated priapism in sickle cell disease.Blood. 2005;106:3264-7.

11. Pamplona A, Ferreira A, Balla J, Jeney V, Balla G, Epiphanio S, Chora A, Rodrigues CD, Gregoire IP, Cunha-Rodrigues M, Portugal S, Soares MP, Mota MM. Heme oxygenase-1 and carbon monoxide suppress the pathogenesis of experimental cerebral malaria. Nat.

Med. 2007;13:703-10.

12. Hebbel RP, Morgan WT, Eaton JW, Hedlund BE. Accelerated autoxidation and heme loss due to instability of sickle hemoglobin. Proc. Nat. Acad. Sci. U.S.A. 1988;85:237-41.

13. Zhang Y, Dai Y, Wen J, Zhang W, Grenz A, Sun H, Tao L, Lu G, Alexander DC, Milburn MV, Carter-Dawson L, Lewis DE, Zhang W, Eltzschig HK, Kellems RE, Blackburn MR, Juneja HS, Xia Y. Detrimental effects of adenosine signaling in sickle cell disease. Nat. Med. 2011;17:79-86.

14. Gladwin MT, Vichinsky E. Pulmonary complications of sickle cell disease. N. Engl. J. Med. 2008;359:2254-65.

15. GargiSen, IndranilChakraborty, Santa-Saha Roy, SubhenduChoudhury, DebashishBhattacharya, KoushikBannerjee. Serum lactate dehydrogenase and adenosine deaminase as predictors of hemolysis in children with hemolytic anaemia. International Journal of Pharmaceutical, Chemical and Biological Sciences.2014;4(3):5127.

16. Reed JD, Redding-Lallinger R, Orringer EP. Nutrition and sickle cell disease. Am J Hematol. 1987;24:441-55.
17. Dubert M, Elion J, Tolo A, Diallo DA, Diop S, Diagne I, et al. Degree of Anemia, Indirect Markers of Hemolysis, and Vascular Complications of Sickle Cell Disease in Africa. Blood. 2017 Sep 20.

18. Woods KF, Ramsey LT, Callahan LA, Mensah GA, Litaker MS, Kutlar A, et al. Body composition in women with sickle cell disease. Ethn Dis. 2001;11(1):30-5.

19. Zivot A, Apollonsky N, Gracely E, Raybagkar D. Body Mass Index and the Association With Vasoocclusive Crises in Pediatric Sickle Cell Disease. J Pediatr Hematol Oncol. 2017 May;39(4):314-7.

20. Nikhar HS, Meshram SU, Shinde GB. An anthropometric and hematological comparison of sickle cell disease children from rural and urban areas. Indian J Hum Genet. 2012 Jan;18(1):40-2.

21. Cepeda ML, Allen FH, Cepeda NJ, Yang YM. Physical growth, sexual maturation, body image and sickle cell disease. J Natl Med Assoc. 2000;92:10-4.

22. Odetunde OI, Chinawa JM, Achigbu KI, Achigbu EO. Body mass index and other anthropometric variables in children with sickle cell anaemia. Pak J Med Sci. 2016 Apr;32(2):341-6.

23. Rees DC, Williams TN, Gladwin MT. Sickle-cell disease. Lancet. 2011;376:2018-31. 